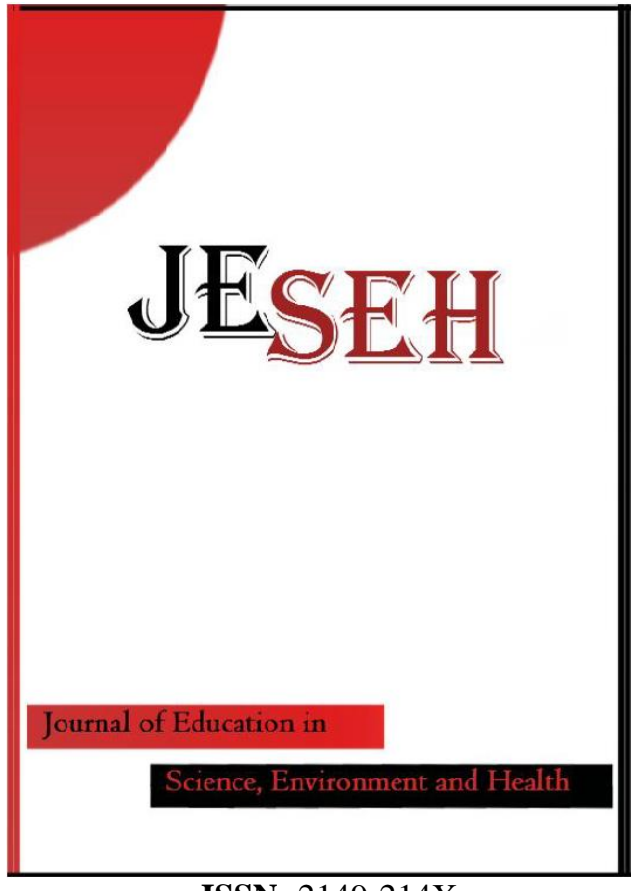

ISSN: $2149-214 \mathrm{X}$

\section{Journal of Education in Science,} Environment and Health

www.jeseh.net

Effects of Place-Based Socioscientific Issues on Rising Middle School Students' Evidence-Based Reasoning and Critical Thinking on Hydraulic Fracking

\section{Wardell A. Powell}

Framingham State University

To cite this article:

Powell, W.A. (2021). Effects of place-based socioscientific issues on rising middle school students' evidence-based reasoning and critical thinking on hydraulic fracking. Journal of Education in Science, Environment and Health (JESEH), 7(3), 220-242. https://doi.org/10.21891/jeseh.961002

This article may be used for research, teaching, and private study purposes.

Any substantial or systematic reproduction, redistribution, reselling, loan, sub-licensing, systematic supply, or distribution in any form to anyone is expressly forbidden.

Authors alone are responsible for the contents of their articles. The journal owns the copyright of the articles.

The publisher shall not be liable for any loss, actions, claims, proceedings, demand, or costs or damages whatsoever or howsoever caused arising directly or indirectly in connection with or arising out of the use of the research material. 


\title{
Effects of Place-Based Socioscientific Issues on Rising Middle School Students' Evidence-Based Reasoning and Critical Thinking on Hydraulic Fracking
}

\author{
Wardell A. Powell
}

\begin{tabular}{|c|c|}
\hline Article Info & Abstract \\
\hline Article History & $\begin{array}{l}\text { This study investigated the implementation of a place-based socioscientific issue } \\
\text { curricular unit designed to improve rising middle school students' abilities to }\end{array}$ \\
\hline $\begin{array}{l}\text { Published: } \\
\text { 01 July } 2021\end{array}$ & $\begin{array}{l}\text { think critically about the pros and cons of hydraulic fracturing and engage in } \\
\text { evidence-based reasoning on whether the practice should be banned in }\end{array}$ \\
\hline $\begin{array}{l}\text { Received: } \\
\text { 30 January } 2021\end{array}$ & $\begin{array}{l}\text { Massachusetts. Forty-three rising middle school students from a summer } \\
\text { enrichment program for science, mathematics, reading and writing operated by a } \\
\text { non-profit organization in the northeastern United States participated in this }\end{array}$ \\
\hline $\begin{array}{l}\text { Accepted: } \\
10 \text { April } 2021\end{array}$ & $\begin{array}{l}\text { study. The instructional unit exposed the students to information and activities } \\
\text { on hydraulic fracturing for five consecutive days ( } 50 \text { minutes each day). The } \\
\text { findings from this study showed that through productive socioscientific issues }\end{array}$ \\
\hline Keywords & $\begin{array}{l}\text { pedagogy, the students used the evidence collected from their investigation to } \\
\text { engage in evidence-based reasoning about the cost and benefits of hydraulic }\end{array}$ \\
\hline Socio & fracturing on the public health, economy, and the environment. The students \\
\hline Hydraulic fracturing & used their understanding of the science and engineering practices to construct \\
\hline & valid arguments on whether or not hydraulic fracturing should be allowed in \\
\hline Critical thinking & $\begin{array}{l}\text { their state. The results further indicate that the use of socioscientific issues as a } \\
\text { critical pedagogical strategy can equip students with the skills necessary for } \\
\text { them to become better advocates for themselves and their communities. }\end{array}$ \\
\hline
\end{tabular}

\section{Introduction}

It has been nearly three decades since the first reported study on environmental racism in the United States (Bryant \& Mohai, 1992). Since this first study was done, numerous policy makers from the local, state, and federal government across the United States have condemned the practice of environmental racism. Yet, many minority communities are still experiencing daily health-related risks due to living in polluted environments. While proactive governmental policies are required to address these environmental inequities, one question remains: how can education in general, and science education in particular, help to bring about much-needed changes to the environmental racism that are constantly perpetuated on marginalized communities? One train of thought lies in the necessity to implement socioscientific issues (SSI) pedagogy in the K-12 curricula to expose students to place-based education. The SSI framework seeks to provide opportunities for students to develop competencies engaging in discourse on scientific issues impacting their communities. The purpose of this study is to describe the effects of a place-based socioscientific issues instructional unit of instruction on rising middle school students' abilities to engage in evidence-based reasoning and to think critically about hydraulic fracking as they determine whether to ban fracking in Massachusetts. Outlined below is an SSI unit on hydraulic fracking, the teaching strategies adapted, and the results obtained from a group of rising middle school students in the northeastern United States. The issue of hydraulic fracturing was used as a place-based educational opportunity to engage the students in evidence-based reasoning on the effects of hydraulic fracking on the environment.

\section{Literature Review}

There are no secrets that racial minority and low-income communities across the United States are disproportionally impacted by environmental risks associated with pollutants (Powell \& Fuchs, 2020, Cutter, 1995, USEPA, 1992a). Studies have shown that it is quite common that waste disposal sites are often located in minority communities, away from individuals who receive the majority of the benefits that are associated with the events that generate the waste (Griffith et al., 1989, Norton, 2007, Lowman, 2013, Johnson, 2016). Throughout the United States, waste disposal facilities are disproportionally located in communities of color 
(Bullard, 2008, Bryant, 1992, Powell \& Fuchs, 2019). This unequal pattern of distributing waste treatment facilities in marginalized communities comes with a price, as residents who live in these areas often bear the brunt of health-related illnesses that are caused by the pollutants from these industries (Davis, 2018; Singer, 2011). For example, in the Standard Heights community of Louisiana, an area of the state called "Cancer Alley" because of the pollutants from the petroleum industries in the area, studies have reported that residents often developed strange sores on their feet that don't heal, sinus infections, odor smelling air, and deposits on everything that is outdoors (Keehan, 2018). Studies have reported that it is a common occurrence for residents who live along the Mississippi River to die at a young age from cancer and lung disease (Keehan, 2018).

Other studies have also reported that petrochemical accidents that results in spillage into the environment is not new (Allen, 2003, Louisiana Department of Environmental Quality 1997).). For example, in 2012, the Exxon plant bordering Standard Heights in Louisiana spilled 31,000 pounds of cancer-causing benzene into the air. After this event many residents of the community became ill. While this was the case, this accident was not reported to the Environmental Protection Agency (EPA). These practices often resulted in great fear among people who live in marginalized communities where petrochemical industries are constructed, whether these industries are conventional or unconventional oil and gas industries. For example, unconventional oil and gas technique such as hydraulic fracturing that combines horizontal drilling with pressurized high-volume injection of fluids to fracture underground shale rocks to release trapped oil or gas is practiced in many regions of the United States. This practice is a subject of contention among the two political parties in the 2020 presidential election in the United States. While both political parties debate the issue of hydraulic fracturing, this practice is on the increase throughout the United States. For example, it was estimated that as of 2012, the United States has approximately 100,000 unconventional oil and gas wells in several states (Ellsworth, 2012). Each of these wells requires 11 to 19 million liters of water for drilling (US Environmental Protection Agency, 2015). In each well, sand and other additives that are known to have adverse health risks are also injected (Colborn, et al., 2011). An estimated 5.2 million liters of fracking fluid returns to the surface from each well as waste water (Lutz, et al., 2013; Ferrar et al., 2013). One can expect that the management of this waste water pose significant threats to drinking water resources, and ultimately public health (Vengosh et al., 2014; Yuan et al., 2013). The events of Cancer Ally, and the impact of the health of the residents who live in these eighty-five miles stretch of land that borders the Mississippi River from Baton Rouge to New Orleans should create enough cause for concerns about hydraulic fracturing. Therefore, it is imperative that school science develop generations who can ask the right questions of their elected officials, to analyze the data associated with hydraulic fracturing, and make inform decisions on the issue, requires an educational system that utilizes place-base education as a key instructional strategy. The use of the SSI in the K-12 science education curriculum is poised to enhance students' abilities to engage in these actions.

\section{Socioscientific Issues and its Impact on Place-Based Education}

Whether we are talking about the disproportionate numbers of waste treatment facilities in communities of color (Bullard, 2008, Bryant, 1992, Powell \& Fuchs, 2019), health-related illnesses that are caused by the pollutants from these industries (Davis, 2018; Singer, 2011), or America's quest for energy independence, these scientific issues make it is quite clear that school science must provide the framework on which youth can take civic actions that are aimed at protecting their communities from the fallout that may result from these industries. This is needed in order to preserve the health of the residents who live in marginalized communities throughout the United States and other parts of the world. One way to accomplish this goal is for school administrators, science supervisors, and science teachers to make SSI part and parcel of the school science curriculum. SSI are scientific issues that are typically contentious issues, can be considered from a variety of perspectives, do not possess simple conclusions, and frequently involve morality and ethics (Zeidler \& Kahn, 2014). Examples of SSI include, but are not limited to a range of dilemmas such as hydraulic fracking, biotechnology, health effects of diets, as well as genetic engineering (Sadler \& Murakami, 2014; Zeidler \& Kahn, 2014). The SSI framework seeks to involve students in decision making regarding everyday social issues with moral or ethical implications embedded within scientific contexts (Yap, 2014). Hydraulic fracturing practices in the United States have garner supports because of its potential of helping the United States to wean itself off of foreign oil. While this is the train of thoughts by supporters of hydraulic fracturing, others are vehemently opposed to the practice because of the potential risks it poses to the environment and public health. Introducing students to scientific issues, such as hydraulic fracturing that lacks clear cut solutions has the potential to enhance their ability to analyze, synthesize and evaluate information, develop their moral reasoning and ethical decision-making skills, in addition to improving students' content knowledge and argumentation abilities (Dawson \& Venville, 2010; Klosterman \& Sadler, 2010; Sadler, Klosterman, \& Topcu, 2011). These skills are critical in promoting civic engagement among students. Currently, our science education policy promotes the idea that scientific 
understanding is all students need to make informed scientific decisions (e.g., AAAS, 1989; NRC, 2012). However, studies have shown that scientific understanding is not enough to impact the decisions people make on civic engagement (Allum et al., 2008; Sadler, 2004). For example, studies that have investigated secondary school students' willingness to act to reduce climate change have reported that while students are willing to turn off lights and unplug electrical appliances when not in use (Chokker et al., 2010; Hermans \& Korhonen, 2017; Skamp et al., 2009), they are less likely to less likely to purchase used items to preserve natural resources, or to reduce their carbon footprints by walking moderate distances (Hermans \& Korhonen, 2017). Therefore, students in the K-12 system need more opportunities that promote civic engagement aimed at protecting the environment should be explicitly taught in the school settings. The use of SSI in the science classroom is position to promote more civic engagement among students.

In a recent study, Birmingham and Barton (2014) engaged youth from underrepresented backgrounds in an after-school science program in the Great Lake City area of Michigan that was designed so that the youth could examine SSI as they took educated action in science. As a culminating activity, the youth hosted parents, peers, and other community members at a "green carnival" who were interested in learning more about green energy. The youth wanted to educate their community members about green energy, why it matters, and what community members can do at home to be green. Based in the research the youth did prior to the carnival, they felt that they had become "experts" on these topics, and had ideas they wanted to share with community members. At the "green carnival," the youth messages to their community members include information on energy efficiency and technological advances, energy and the environment, and renewable energy technology. The youth conveyed information, showcase exhibits, and demonstrated experiments to their community members who attended the green carnival specific practices they hoped community members would enact at their home. For example, in teaching their community members about energy efficiency and technological advancements, the youth created a Light Bulb Efficiency exhibit that provided opportunities for community members to interact. The community members were able to speculate which light bulb is more efficient, and determine which light bulb is better for home use. This exhibit was designed to teach community members about energy efficiency. The three girls who led this exhibit used their scientific knowledge about how light bulbs work, energy usage, how energy usage is measured, and energy transformation to community concerns, and potential actions that community members can take to enhance their energy efficiency at home.

Birmingham and Barton (2014) reported that the youth effectively engaged their community members on other exhibits that included renewable energy technology, energy and the environment (for more details see Birmingham and Barton, 2014 study). These researchers reported that:

... we argue that the specific design of the carnival itself was intended to make green energy issues accessible, salient, and interesting to the community in response to how they understood their community's knowledge of green energy. We believe that these forms of educated action allowed the green carnival to open dialog and foster interaction within science among community members. (p. 306).

The finding from Birmingham and Barton, (2014) highlight the potential impact of using SSI to educate students and community members on actions that can be taken to preserve natural resources and the environment in which one live. The ill-structured nature of hydraulic fracturing is a great SSI activity that can be used to enhance students' argumentation quality, decision-making skills, and civic engagement. This is because the issue of on hydraulic fracturing is ill-structured in nature, as a result it presents numerous pros and cons on which students can engage in meaningful discourse on whether the practice should be banned. This is a place-based issue that is concerning for residents who get their potable water from aquifers in and around areas where hydraulic fracturing is occurring or is slated to occur. For example, several bills have been proposed in Massachusetts House to ban hydraulic fracturing in the Commonwealth. In 2016, Massachusetts Senate approved Senate, No. 2309, that place a ten-year moratorium on fracking and the disposal of fracking wastewater in the Commonwealth. While this is the case, there are other areas of the United States where hydraulic fracturing is occurring un-impeded. One of the main reasons is that the link between direct contamination to drinking water resources as a result of hydraulic fracturing activities is still being investigated. For example, Barth-Naftilana, Sohnga, \& Saiersa (2018) conducted a 2-year prospective study of groundwater quality within the Marcellus Shale. This study installed eight multilevel monitoring wells within bedrock aquifers of a 25-kilometers square area targeted for shale gas development. The study reports that twenty-four isolated intervals within these wells were sampled monthly over two years, and groundwater pressures were recorded before, during, and after seven shale gas wells were drilled, hydraulically fractured, and placed into production. This study found no lasting impact on groundwater quality from hydraulic fracturing. While this is the case, residents are still on edge about hydraulic fracturing. 
One of the chief concerns from citizens is that groundwater wells located closer to hydraulically fractured sites are more likely to be exposed to contamination. Jasechko and Perrone (2017) conducted a study that analyzed the distance between domestic groundwater wells (public and self-supply) constructed between 2000 and 2014 and hydraulically fractured wells stimulated in 2014 in 14 states. They reported that $37 \%$ of all recorded hydraulically fractured wells stimulated during 2014 exist within $2 \mathrm{~km}$ of at least one recently constructed (2000-2014) domestic groundwater well. These findings create cause among residents in communities where hydraulic fracturing is occurring because studies have found methane in drinking water wells in regions where hydraulic fracturing occurs. For example, Osborna et al. (2011) conducted a study investigating methane contamination of drinking water accompanying gas-well drilling and hydraulic fracturing. This study reports that methane concentrations were generally detected in 51 of 60 drinking-water wells $(85 \%)$ in the region where the Marcellus and Utica shale formations of northeastern Pennsylvania and upstate New York. The study reports that methane was detected in drinking water wells regardless of gas industry operations, but concentrations were substantially higher closer to natural-gas wells. The study also notes that methane concentrations were 17-times higher on average in shallow wells from active drilling and extraction areas than in wells from nonactive areas.

In this study, Osborna et al. (2011) also reported that they found no evidence for contamination of drinkingwater samples with deep saline brines or fracturing fluids. These researchers conclude that greater stewardship, data, and-possibly - regulation are needed to ensure the sustainable future of shale-gas extraction and to improve public confidence in its use (Osborna et al., 2011, p. 8172).

Knowing that hydraulic fracturing is currently occurring in many established oil and gas producing regions of the United States makes it an essential place-based educational issues that school science education curriculum should address. This will undoubtedly add opportunities for school science to engage K-12 students in real world scientific discourse, which can potentially impact students' evidence-based decision-making skills.

\section{What is Place-Based Education?}

Many have argued that place-based education enhanced students' understanding of the interdependent relationship between their lives and the various systems within their communities (Lewicki, 1998; Howley \& Howley, 2010; Theobald, 1997). While place-based education has a long history in rural schools and communities (Howley \& Harmon, 2000; Howley et al., 2008; Jennings et al., 2005), it is important to point out that threats to the public drinking water resources as well as health-related dangers to the environment are concerns that are shared by citizens from all locations, both urban and rural. Therefore, the use of place-based education in the K-12 curricula should be a point of interest for all because of its potential in providing students with opportunities for learning in authentic ways (Sarkar \& Frazier, 2008). It also has the potential to enhance students' argumentation quality, decision-making skills, and civic engagement

But what exactly is place-based education, and is it appropriate for the science classroom? David Sobel (2004) reported that:

Placed-based education is the process of using the local community and environment as a starting point to teach concepts in language arts, mathematics, social studies, science, and other subjects across the curriculum. Emphasizing hands-on, real-world learning experiences this approach to education increases academic achievement, helps students develop stronger ties to their community, enhances students' appreciation for the natural world, and creates a heightened commitment to serving as active, contributing citizens. Community vitality and environmental quality are improved through the active engagement of local citizens, community organizations, and environmental resources in the life of the school. (p. 7).

Based on Sobel's (2004) definition, it is clear that place-based education has the potential to immerse students into community issues that can be tied to all school subjects. Such teaching approach is paramount in facilitating the creation of engaged students, better future citizens, improved communities, awareness of preserving the natural environment, and higher academic achievement (2010).

As educators think about how to make science curriculum relevant to students' lives, connecting the school science curriculum to scientific issues that plague the communities in which students live presents students with opportunities to think fruitfully about how their actions or inactions may impact their communities. Place-Based Education in the school science curriculum can provide a set of circumstances for students to examine data, reason, make conclusions, and think critically to challenge injustices perpetrated on their communities by 
powerful others. However, instituting place-based Education in the school science curriculum will require teachers to put away the science textbook as the communities' scientific problems are not often represented in the textbooks students are asked to read. Instead, teachers must align the place-based education topics they want to discuss in their classroom to their state curriculum standards. Doing so will provide opportunities for teachers to integrate science education with other disciplines that will (re)consider new politico-ethical directions (Carter 2011).

The SSI unit on hydraulic fracturing described in this article presented the opportunity for these students who are from a major metropolitan area in Massachusetts to engage evidence-based discourse on a place-based education topic that creates contention in many communities throughout the United States. The students' abilities to navigate this issue may impact their skills to make evidence-based reasoning central to their decision on whether hydraulic fracturing should be banned in Massachusetts.

\section{Method}

The framework for K-12 science education sets a very ambitious goal for all students within the system. The overarching goal of the framework states:

By the end of 12th grade, all students are to have some appreciation of the beauty and wonder of science; possess sufficient knowledge of science and engineering to engage in public discussions on related issues; are careful consumers of scientific and technological information related to their everyday lives; are able to continue to learn about science outside school; and have the skills to enter careers of their choice, including (but not limited to) careers in science, engineering, and technology (National Research Council [NRC], 2012).

One way of facilitating the overarching goal of the framework is to provide opportunities for K-12 students to connect events of their communities to the school curriculum authentically. Doing so will enable students to make a more meaningful connection between the things they learn in school and the events that are happening in their communities. Therefore, in an attempt to satisfy the framework's goal, the following questions and corresponding rationales were used to guide this investigation.

\section{Research Question 1}

What relationships, if any, exist between place-based education on students' abilities to engage in evidencebased reasoning?

\section{Rationale 1}

Advocates of the SSI framework have argued that such pedagogy has the potential to develop students' competencies in making evidence-based decisions on sustainable environmental practices (Bencze et al., 2012, Mueller et al., 2011, Powell \& Fuchs, 2019). The potential scientific problems that stem from hydraulic fracturing pose a serious threat to the health and survival of the citizens who live within communities where hydraulic fracturing is conducted. Determining the cause and effects relationships between hydraulic fracturing on public health will require a generation who can engage in the cause and effects investigation of hydraulic fracturing in addition to critically think about the potential ramification of such practice. Sound pedagogy is a requirement for students to determine potential relationships between hydraulic fracturing and the health of the environment. SSI as a pedagogical strategy is poised to enhance students' abilities to think critically as they determine cause and effects relationships and engage in evidence-based reasoning on science issues such as energy consumption and production that relates to their everyday lives.

\section{Research Question 2}

How might middle school students' abilities to think critically about hydraulic fracking impact their decisionmaking on whether to ban fracking in Massachusetts?

\section{Rationale 2}


Enhancing students' critical thinking abilities requires an extensive, deliberate practice that involves the use of argument mapping (Mulnix, 2010). Such beliefs are aligned with the vision for K-12 science education advocated by the NRC (2012). For students to become the critical consumer of science, they must get opportunities to use critique and evaluation to judge the merits of any scientifically based argument (NRC, 2012). However, achieving this goal is only possible if teachers adapt and use sound pedagogical practices in the classroom settings that foster the development of students' abilities to use critique and evaluation to judge the merit of an argument (Powell \& Fuchs, 2019). The use of SSI as a key pedagogical strategy has the potential to enhance students' critical thinking abilities as they engage in argumentation exercises on scientific issues that are personally relevant and meaningful to their daily lives.

\section{Study Participants and Context}

The participants of this study were 43 rising middle school students (11-12-years-old; 20 males, 23 females) who participated in a summer enrichment program for science, mathematics, reading, and writing operated by a non-profit organization in the northeastern United States. The goal of the organization is to develop and implement programs that prepare underserved students in the northeastern United States for educational opportunities that lead to college success. The program remediates achievement gaps and prepares students for acceptance to and success at top independent, Catholic, and public exam schools in the Northeastern United States. The students are generally referred to the program by their teachers from the public-school system, and they are admitted in the spring before their fifth or sixth-grade year. The racial breakdown of the students is as follows: 19\% Asian, 37\% Black, 21\% Hispanic, 10\% Multiracial, 4\% White, and 9\% other. These students were from 40 distinct feeder schools. Seventy-seven percent of the students attended public schools, nineteen percent attended charter schools, and four percent attended parochial schools. The average family income was $\$ 41,735$, and fifty-one percent of the students qualify for free and reduced meals.

\section{Data Generation and Implementation Process}

The instructional unit was done over six consecutive class periods. Each class period lasted for 55 minutes. Students' written artifacts were collected each day and analyzed. Below is a description of the day's events:

Day 1:

The Center for Local, State, and Urban Policy at the University of Michigan conducts, supports and fosters applied academic research to inform local, state, and urban policy issues. Questions 3, 14, 15, 17, and 25 from the center's survey on the public perceptions of shale gas extraction and hydraulic fracturing in New York and Pennsylvania (Borick, Rabe, \& Lachapelle, 2014) were used to create pre/posttest surveys for this unit. The pretest was administered at the beginning of the unit of study, while the post test was administered at the end.

After administering the pretest, a brief YouTube video, "The Frack Attack" was used to introduce the students to the term fracking (https://www.youtube.com/watch? $v=i I L U x u m U u 40$ ). The idea behind this was to show the pros and cons of hydraulic fracturing and to see if the students could pick up on any bias of this particular news coverage. After the students watched the video, the See-Think-Wonder technique (Harvard Graduate School of Education, 2009) was used to engage students in inquiry-based thinking through close observation (Powell \& Fuchs, 2019). The students' prior knowledge on the topic as well as any misconceptions, feelings, fears, or ideas regarding the topic were gathered by this technique. The students were then asked to determine if hydraulic fracturing should be allowed in Massachusetts and to give their initial reasons for their stance. This was done so that the students could generate their own claims on hydraulic fracturing. This initial stance taking was used as a starting point which the students revisit throughout the unit as they gain further knowledge on the topic.

To introduce the students to the topic of hydraulic fracturing in greater depth, they were assigned an article that tells what is fracking, where fracking is taking place internationally, how the process is done, and the cost and benefits of fracking (http://www.bbc.com/news/uk-14432401). The 'Jig-saw' technique (Slavin, 1990) was used for this reading activity. The students were divided into small groups. Each student was assigned a task. They searched for these words/phrases in the article. Under "Context", write the sentence in which the word appears. Under "Definition", provide the meaning of the word. 
The students were also required to identify the pros and cons of fracking that were discussed in the article. They identified the pros and cons in the graphic organizer below. Representing the pros and cons in the graphic organizer allowed the students to organize their thoughts in a cohesive way and help them distinguish the different sides presented in the article.

The students were asked to deconstruct the shale gas extraction picture in the article and to highlight the steps taken in the fracking process based on the item and the image. The students were asked to use the picture to help remind them of the fracking process in addition to helping the students to understand the process visually. This enhanced their abilities to break down the steps from the article; they could use the illustration as a guiding point.

Day 2:

The students were asked to respond to the following questions:

a) What is fracking?

b) What is the purpose of fracking?

After answering these questions, the students were provided with a video that shows the steps of fracking (https://www.nationalgeographic.org/media/how-hydraulic-fracturing-works/). Based on the information provided in the video, the students were asked to determine the risks that are associated with each step. Finally, the students were asked to respond to the following questions:

a) What potential impact does fracking have on the environment?

b) Did your opinion on fracking change after this activity?

Day 3:

The students were assigned the Newsela article titled, "Issue Overview: Fracking" (https://newsela.com/read/overview-fracking/id/21698/). This article was assigned to reinforce the students' reading comprehension and point of view for the pros and cons of fracking. This was done so that the students could better solidify their stance on fracking. The students were asked to read and take note of the various positions on fracking and then come up with their lists in groups. This allows them to organize better the information that is presented to them in the article.

The students were then presented with a unique way to share their thoughts on the article. They were asked to use Twitter-style ( 280 characters) response to summarize the main point of the article. The students were very engaged in this activity to the point where they calculated the number of characters in their summary to ensure they were able to express their view accurately with no fewer characters.

Day 4:

The students responded to the question, should fracking be outlawed in Massachusetts? The students were asked to record their responses to the above question in the graphic organizer below. This graphic organizer allowed the students to build upon the previous day's work by requiring them to pick a stance on fracking, use reasons, provide evidence from their research, and record these in the graphic organizer below. Having this graphic organizer allows the students to organize their point of view in a meaningful way.

Day 5:

The students engaged in a whole class debate on whether fracking should be banned in Massachusetts. This place-based education assignment is meant to be a formative assessment of the students' knowledge of the process of fracking. This allowed the students to further elaborate on the evidence they have gathered. Students had already gathered evidence over the past few lessons, formed opinions/claims based on evidence and reasoning, and now have the chance to pick a side and debate with their peers whether or not fracking should be 
allowed in their local region. This was done so that students have a closer connection to the topic-if the topic is close to home, it will be more meaningful to the students.

Day 6:

For a final reflection on hydraulic fracturing, the students were assigned the following questions:

a) What was your position on fracking at the beginning of the unit (day 1)?

b) Did your position change? Why or why not?

c) Was your opinion swayed by any of the information that your peers presented in the debates or posters? Why or why not?

d) What is the purpose of fracking?

These questions were used as a summative assessment of the unit to gauge how effective the unit was as a whole. It tells whether or not the misconceptions of the students changed based on the research they've conducted as well as how much of an impact the SSI topic of fracking had on the students overall.

\section{Study Design/Procedure}

This study employed the use of a critical ethnography design. The use of this design allowed for a more extensive examination of the political, social, and economic issues that focus on oppression, conflict, struggle, power, and praxis (Schwandt, 1997, p. 22). Based on the research literature, critical ethnography is rooted in research which recognizes that some with power dominate and exploit the less powerful either overtly or covertly, and rather than identifying the imbalance, seek to create fundamental social change through power (Ross et al., 2016; Carspecken, 1996; Denzin \& Lincoln, 2011; LeCompte \& Schensul, 1999; Smyth \& Holmes, 2005). The potential fallout from hydraulic fracturing on peoples' health, the environment, and the economy provided us with the opportunity to use this study to examine the students' abilities to engage in evidence-based reasoning, to think critically about hydraulic fracking as they determine whether to ban fracking in Massachusetts.

The data gathered presents an in-depth understanding of the students' abilities to think critically about whether hydraulic fracturing should be banned in Massachusetts because of the potential detrimental health effects on drinking water resources and the environment, as well as the students' abilities use evidence-based decision reasoning to substantiate their claim. The senior director of teaching and learning for the non-profit organization randomly assigned three classes to the SSI curriculum. The author taught all three classes. The students in these classes were given the pre-test questionnaire, exposed to the SSI instructional unit and activities, and then given the post-test questionnaire.

\section{Data Analysis-Use Critical Thinking Tenets from Diversity Work}

The students' responses to the pretest and posttest were tabulated to identify changes in the students' exposure to and beliefs about the impact of hydraulic fracturing on the economy, public health, and the environment. A constant comparative method of analysis (Glaser \& Strauss, 1967) on the students' suggested course of actions and justifications were conducted to identify emergent themes. The author and the two post-baccalaureate teacher candidates with qualitative data analysis experience were involved in the data analysis process. The data analysis process was divided into three phases. The first phase of the analysis examined themes apparent in days 1-6 artifacts generated from the students' responses to various items and activities. We identified segments of the data from the various days that included information on the students' prior knowledge about hydraulic fracturing, potential misconceptions of the practice, the pros and cons of hydraulic fracturing, and the students' feelings and fears regarding the effects of hydraulic fracturing on the economy, public health, and the environment. These segments were then coded with respect to themes such as premise, claim, rules, evidence, and data. This analysis allowed us to elaborate on how the students' abilities to engaged in evidence-based reasoning.

In the second phase of the analysis, we examined the students' determination on whether fracking should be banned in Massachusetts. This analysis allowed us to examine the students' abilities to gather complete information about hydraulic fracturing and question the conclusions drawn by their peers. The analysis further 
allowed us to determine the students' abilities to think about the issue, examine the big picture of hydraulic fracturing, consider the cause and effect of fracturing, understand their own bias on the issues, consider others' views, and question the sources of data. The analysis allowed us to elaborate on the students' abilities to think critically about hydraulic fracking as they weigh their decision-making on whether to ban fracking in Massachusetts.

\section{Results and Discussion}

The findings demonstrated how the rising middle students in this study engaged in evidence-based reasoning as they think critically about the pros and cons that are associated with hydraulic fracking as they determine whether to ban fracking in the state of Massachusetts. Details below are the two main areas of findings that are aligned to the two research questions: (1) Relationships between place-based education on students' abilities to engage in evidence-based reasoning, (2) students' abilities to think critically about hydraulic fracking and their decision-making on whether to ban fracking in Massachusetts.

\section{Relationships between Place-Based Education on Students' Abilities to Engage in Evidence-Based Reasoning}

\section{Day 1: Pretest/Posttest}

The issue of hydraulic fracturing has been a hot-button issue in Massachusetts for the last decade. However, it is often common for students in this age group to not follow up or keep abreast of new reports on their local news outlet. Therefore, it is crucial to determine the potential impact that the instructional unit had on the students' level of familiarity with the practice of hydraulic fracturing before and after the instruction unit. As a result, the students were asked to share how much they have heard about the practice of hydraulic fracturing. Figure 1 below shows the question and the pre/posttests results of the students' knowledge of oil and natural gas development through hydraulic fracturing.

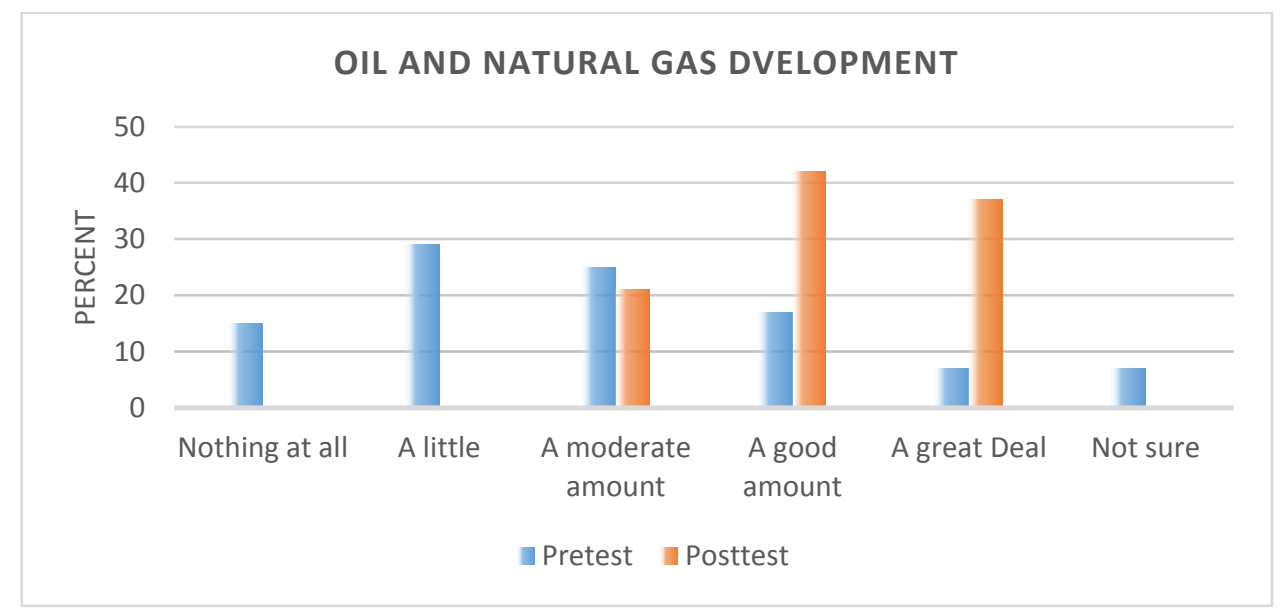

Figure 1. Oil and natural gas development through hydraulic fracturing

The students started the unit not knowing much about oil and natural gas development through the use of hydraulic fracturing. When asked how much they have heard about oil and natural gas development through the use of hydraulic fracturing in the pretest, $28 \%$ of the students stated that they know little, while $15 \%$ stated they know nothing at all. Only, $17 \%$ stated that they know a good amount, while $7 \%$ stated they know a great deal. However, after the student engaged in the instructional unit and conducted their research on hydraulic fracturing, the students improved their knowledge. In the post-test, no students stated that they knew nothing at all or very little about hydraulic fracturing to produce oil and natural gas. In fact, $42 \%$ of the students stated that they know a good amount about hydraulic fracturing, while 37\% stated they know a great amount. It is interesting to note that while some students in the pretest stated that they knew nothing at all about fracking (15\%), and other stating that they know a little about the practice (27\%), the subject has been a contentious issue in Massachusetts to the point where the state has already banned hydraulic fracturing since 2013. Additionally, there have been several protest, rallies, and news articles about banning hydraulic 
fracturing in the commonwealth of Massachusetts (Cooney, 2019; Annear, 2014; Weiskel \& Green-Weiskel, 2017). Exposing the students to the contentious issue of hydraulic fracturing that has been debated and legislated in their states was used to get the students excited to the extent that they would add to the conversation as they make important decisions whether to ban hydraulic fracturing in Massachusetts.

During some of the rallies in opposition to hydraulic fracturing nationwide, people often consider the harmful effects at the expense of thinking about their local economy's potential benefits. Therefore, the students were asked to indicate if they believe the use of hydraulic fracturing has a positive effect, adverse effect, or no effect on the economy. Figure 2 below shows the pre/posttests results of the students' beliefs of hydraulic fracturing on the economy.

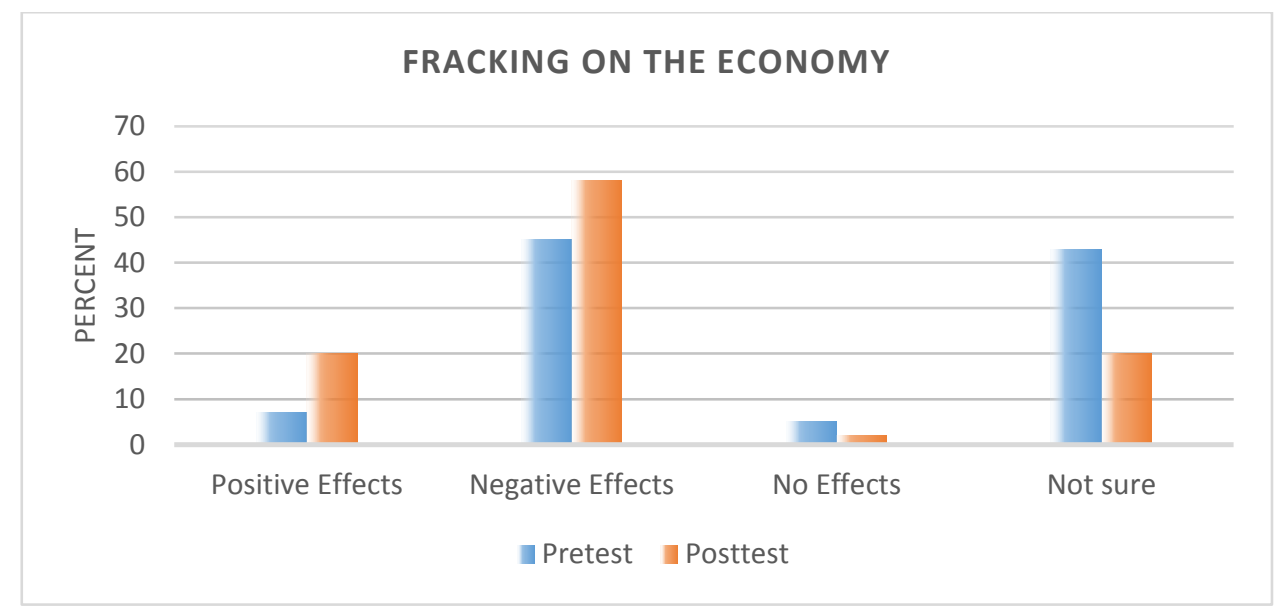

Figure 2. Hydraulic fracturing effects on the economy

When asked in the pretest to indicate if the use of hydraulic fracturing is having a positive effect, negative effect, or no effect on the economy, $42 \%$ of the students in the pretest were unsure of the impact of hydraulic fracturing on the economy while $45 \%$ stated that hydraulic fracturing will have a negative effect on the economy. In the post-test, $20 \%$ of the students were uncertain of the impact of hydraulic fracturing on the economy. This indicate a $22 \%$ reduction between pre and post test results/. However, more student (58\%) stated that hydraulic fracturing would harm the economy. To further measure the impact of the instructional unit on the students' abilities to critically think about the effects of hydraulic fracturing on their communities, they were asked to indicate their beliefs of hydraulic fracturing on public health. Figure 3 below shows the students' pre/posttests thoughts regarding the impact of fracking on public health.

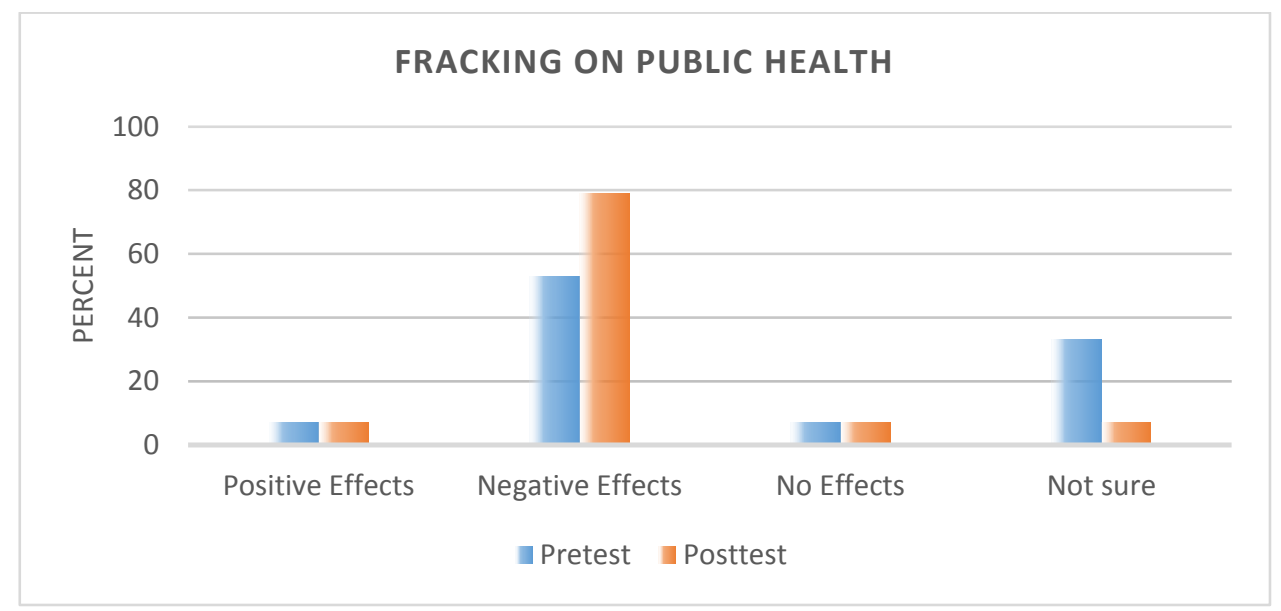

Figure 3: Hydraulic fracturing effects on public health

When asked in the pretest to indicate if the use of hydraulic fracturing is having a positive effect, adverse effect, or no effect on public health, $53 \%$ of the students stated the process will have adverse effects, while $33 \%$ of the students were unsure of the impact. In the posttest, there was a drastic change in the students' belief, as $79 \%$ of the students stated that hydraulic fracturing harm public health. Interestingly, only $8 \%$ of the students were 
unsure of the impact after the exposure to the unit. Figure 4 below shows the students' pre/posttests thoughts regarding the impact of hydraulic fracturing on the environment.

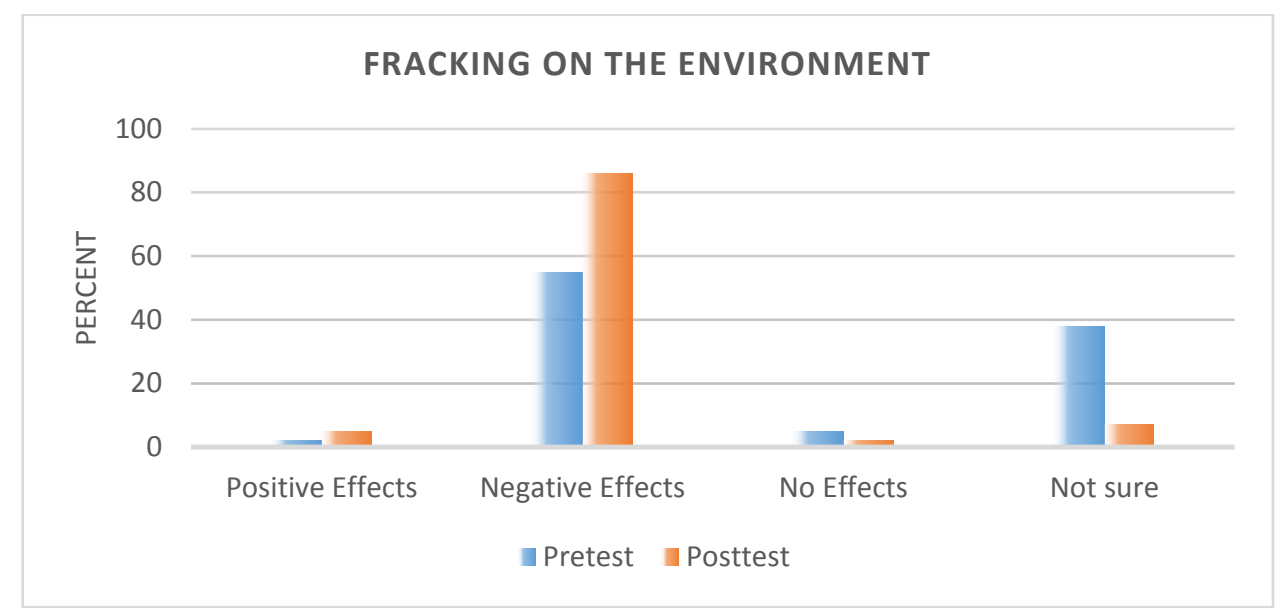

Figure 4. Hydraulic fracturing effects on the environment

When asked in the pretest to indicate if the use of hydraulic fracturing is having a positive effect, adverse effect, or no effect on the environment, 55\% of the students stated hydraulic fracturing harmed the environment. Approximately, 38\% of the students were unsure of the impact that hydraulic fracturing has on the environment. However, after exposure to the unit on fracking, $84 \%$ of the students stated that hydraulic fracturing would hurt the environment. Only $7 \%$ of the students were unsure of its effects on the situation after exposure to the unit on fracking. Figure 5 below shows the students' thoughts when they hear the term fracking.

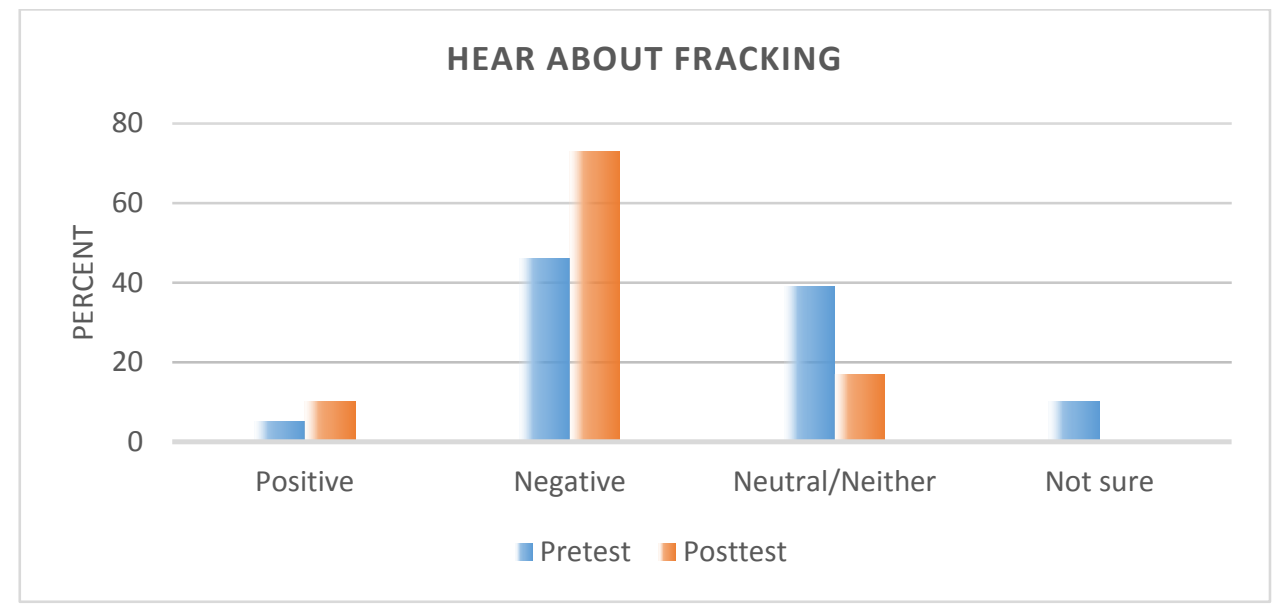

Figure 5. Consideration of fracking

In the pretest, $46 \%$ of the students stated that when they hear the word "fracking," they consider it a negative term. Also, in the pretest, $39 \%$ of the students indicated they neither consider it positive or negative when they hear the word fracking. However, in the posttest, $73 \%$ of the students stated they believe the term fracking is negative. Approximately, $17 \%$ of the students indicated they neither consider the term positive or negative when they hear it. While $49 \%$ of the students stated in the pretest that they were neutral or not sure if they felt positive or negative, only $17 \%$ of the students retained these thoughts after exposure to the unit on fracking.

Although the students started off the instructional unit not knowing much about hydraulic fracturing, it seems as if their review of literature from the research they conducted provided more information on the dangers to hydraulic fracturing. The students talked about the potential of hydraulic fracturing rendering the United States in becoming energy independent. They also stated that the process will create good paying jobs. However, when they read about the potential of hydraulic fracturing contaminating drinking water resources, they stated that the risk far outweighed the benefits. As a result, a greater percentage of the students were opposed to hydraulic fracturing, although the percentage of students those who supported the practice increase slightly by the end of the instructional unit. 


\section{The Controversies of Fracking on Students' Abilities to Engage in Evidence-Based Reasoning}

After administering the pretest, a brief YouTube video, "The Frack Attack" was used to introduce the students to the term fracking (https://www.youtube.com/watch?v=iILUxumUu40). The idea behind this was to show the pros and cons of hydraulic fracturing and to see if the students could pick up on any bias of this particular news coverage. After the students watched the video, the See-Think-Wonder technique (Harvard Graduate School, 2009) was used to engage students in inquiry-based thinking through close observation (Powell \& Fuchs, 2019). The students' prior knowledge of hydraulic fracturing, and thoughts regarding the impact of hydraulic fracturing on the economy, public health, and the environment, were gathered by the see-think-wonder technique. The students then determined if hydraulic fracturing should be allowed in Massachusetts and gave their initial reasons for their stance.

This was done so that the students could generate their claims on hydraulic fracturing and think about the potential ramifications of the practice as they use evidence to determine whether Massachusetts should ban hydraulic fracturing. This initial stance-taking was used as a starting point for the students revisit and gain further knowledge on the topic. The students' written responses were read and re-read to identify instances where the students identify the impact of hydraulic fracturing on the economy, public health, and the environment. Approximately $20 \%$ of the students initially supported hydraulic fracturing in Massachusetts compared to the $80 \%$ who were opposed to the practice. However, by the end of the instructional unit $38 \%$ supported the practice while $62 \%$ opposed. Table 1 below illustrates some of the common reasons the students gave.

Table 1. See-think-wonder about hydraulic fracturing

\begin{tabular}{|c|c|c|}
\hline & Supported Fracking & Opposed to Fracking \\
\hline What did you see? & $\begin{array}{l}\text { There are economic } \\
\text { advantages of fracking }\end{array}$ & $\begin{array}{l}\text { There are health problems } \\
\text { that are associated with } \\
\text { fracking. } \\
\text { Fracking has the potential } \\
\text { to contaminate water with } \\
\text { dangerous chemical and } \\
\text { methane. } \\
\text { Fracking can cause } \\
\text { earthquakes }\end{array}$ \\
\hline \multirow[t]{2}{*}{ What do you think? } & $\begin{array}{l}\text { Fracking is useful to the } \\
\text { economy }\end{array}$ & $\begin{array}{l}\text { Fracking has the potential } \\
\text { to cause health problems } \\
\text { among people }\end{array}$ \\
\hline & $\begin{array}{l}\text { Fracking gives us more } \\
\text { source of energy }\end{array}$ & $\begin{array}{l}\text { Fracking may cause } \\
\text { natural disasters such as } \\
\text { earthquakes }\end{array}$ \\
\hline What do you wonder? & $\begin{array}{l}\text { How to increase safety of } \\
\text { fracking } \\
\text { Why blame these } \\
\text { problems (earthquakes } \\
\text { and methane in drinking } \\
\text { water) on fracking? }\end{array}$ & $\begin{array}{l}\text { Why is fracking so } \\
\text { dangerous? }\end{array}$ \\
\hline
\end{tabular}

These statements were generated from the student's response on the See-Think-Wonder activity they were assigned after they watched the "Frack Attack" video. The students' written responses were read and re-read to identify statements relating to the economy, public health, and the environment. This was done to further align the students' thought process on the hydraulic fracturing pre/post-test items. The students who supported hydraulic fracking identified benefits that fracking will have in the economy and the environment. They stated that it will help the economy because the practice will lead to job creation and more energy. However, these students understood that there is the possibility that fracking might results in contamination to surrounding drinking water resources and inquired about how to conduct the fracturing more safely. They were also skeptical on whether or not hydraulic fracturing results in Earthquakes.

The students who were opposed to hydraulic fracturing stated that it might affect peoples' health, contaminate drinking water sources, and caused Earthquakes. The view hydraulic fracturing as too dangerous and stated that fracking should not be allowed to happen. 
Table 2. Vocabulary role understanding the words you read

\begin{tabular}{|c|c|c|}
\hline Word & Context & Definition \\
\hline $\begin{array}{l}\text { Hydraulic } \\
\text { fracturing/fracking }\end{array}$ & $\begin{array}{l}\text { Refers to how the rock is } \\
\text { fractured apart by high } \\
\text { pressure mixture }\end{array}$ & $\begin{array}{l}\text { It's a technique to } \\
\text { recover gas and oil } \\
\text { from shale rock }\end{array}$ \\
\hline Shale Gas & $\begin{array}{l}\text { Drilling for shale gas is } \\
\text { only at an exploratory } \\
\text { phase in the U.K. }\end{array}$ & $\begin{array}{l}\text { Natural gas occurring } \\
\text { within or extracted } \\
\text { from shale }\end{array}$ \\
\hline Shale Rock & $\begin{array}{l}\text { Shale is a fine-grained } \\
\text { clastic sedimentary rock } \\
\text { composed of mud that is a } \\
\text { mixture of flakes of clay } \\
\text { minerals }\end{array}$ & It is a type of rock \\
\hline Tremor & $\begin{array}{l}\text { A subsequent study found } \\
\text { it was "highly probable" } \\
\text { that shale gas test drilling } \\
\text { triggered the tremors }\end{array}$ & A slight earthquake \\
\hline Energy & $\begin{array}{l}\text { We need } 21^{\text {st }} \text { century } \\
\text { energy revolution based } \\
\text { on efficiency } \\
\text { renewable }\end{array}$ & $\begin{array}{l}\text { Power derived from the } \\
\text { utilization of physical } \\
\text { or chemical resources, } \\
\text { especially to provide } \\
\text { light and heat or to } \\
\text { work machines }\end{array}$ \\
\hline Carcinogenic & $\begin{array}{l}\text { Environmentalists say } \\
\text { potentially carcinogenic } \\
\text { chemical used may escape } \\
\text { and contaminate ground } \\
\text { water around the fracking } \\
\text { site }\end{array}$ & $\begin{array}{l}\text { Having the potential to } \\
\text { cause cancer }\end{array}$ \\
\hline Fossil Fuels & $\begin{array}{l}\text { Not more fossil fuels that } \\
\text { will add for climate } \\
\text { change }\end{array}$ & $\begin{array}{l}\text { A natural fuel such as } \\
\text { coal or gas formed in } \\
\text { the geological past from } \\
\text { the remains of living } \\
\text { things }\end{array}$ \\
\hline
\end{tabular}

To introduce the students to the topic of hydraulic fracturing in greater depth, they were assigned an article that tells what is fracking, where fracking is taking place internationally, how the process is done, and the cost and benefits of fracking (http://www.bbc.com/news/uk-14432401). The 'Jig-saw' technique (Slavin, 1990) was used for this reading activity. For the activity, the students were divided into seven groups. This was done to ensure that at least one student who opposed hydraulic fracturing was in each group. Groups 1-6 consisted had 6 students each, and group had 7 students. The groups assignments are shown below:

Group 1: Hydraulic fracturing/fracking

Group 2: Shale Gas

Group 3: Shale Rock

Group 4: Tremor

Group 5: Energy

Group 6: Carcinogenic

Group 7: Fossil Fuels

Each group read the article and searched for their assigned words/phrases in the article. Under "Context", they write the sentence in which the word/phrase appears. Under "Definition", they provided their meaning of the word/phrase. After 15 minutes reading and discussing the article among themselves, and responding to the task, the groups came together as one group and discuss their groups answers to assigned topic in a whole group setting. Table 2 below shows some common description of the students' thoughts.

The students were clearly able to present definitions of the key words that are associated with fracking in the articles. For example, the students were able to correctly state that hydraulic fracturing is the process of drilling into the earth and injecting high pressure water to get natural gas and oil. They were also able to correctly state what are fossil fuels and the sources of fossil fuels. The students were also required to identify the pros and cons 
of fracking that were discussed in the article. They identified the pros and cons in the graphic organizer below. Representing the pros and cons in the graphic organizer allowed the students to organize their thoughts in a cohesive way and help them distinguish the different sides presented in the article. Table 3 below is a typical example of what one student was able to identify as the pros and cons associated with fracking according to the article.

Table 3. Pros and cons of fracking

\begin{tabular}{lll}
\hline \multicolumn{1}{c}{ Pros } & \multicolumn{1}{c}{ Cons } \\
\hline - Energy independence & $\bullet$ & General risks and dangers \\
- Increase land value & - May explode \\
- Job creation & - Water pollution \\
- No evidence or record of & - Decrease land value \\
- negative environmental effects & & \\
- Help local economies & - Cause earthquakes \\
- Cleaner energy than coal & - Air pollution \\
- Reuse water & - Global warming \\
- Replace coal and other fossil & - Methane gas release \\
- fuels & Produce needed energy & Delays green energy \\
& &
\end{tabular}

In the pros section, the students made the case that the use of fracking will reduce the need to burn so much gas, oil and coal. This they believe will reduce the amount of nitrogen, sulfur, and carbon dioxide in the air, which will make the air cleaner. The students believed that hydraulic fracturing will render the United States to become energy independent, as a constant source of natural gas will reduce the need to rely on foreign oil and gas. Additionally, the students stated that fracking will result in an economic boom as it will create more high paying jobs. As cons, the students stated that fracking might cause tremors which could potentially result in earthquakes. They also voiced their concerns for the leakage of chemicals into the drinking water resources resulting in contamination of drinking water.

\section{Steps in the Fracking Process}

The students were asked to deconstruct the shale gas extraction picture in the article and to highlight the steps taken in the fracking process based on the item and the image. The students were asked to use the picture to help remind them of the fracking process in addition to helping the students to understand the process visually. This enhanced their abilities to break down the steps from the article; they could use the illustration as a guiding point. The students' abilities to break down the steps of hydraulic fracturing from the article were assessed by their abilities to correctly identify the steps in the fracking process. Their written response was assessed for statements relating to the drilling of wells, the injection of high-pressure fracking fluid in the drilled wells, the fracturing of the shale rocks as a result of the injected high-pressure fluid, the fracking proponents that wedge between the fractured shale, and the extraction and storage of the natural gas. All of the students (100\%) were able to identify these basic steps in the fracking process. The students were able to use the picture in the article to recognize that the well is drilled in the shale region before the fracking fluid is pumped into the well. The students were also able to identify the importance of fracturing the shale to extract the gas. The steps the students were able to identify indicated that they were able to use the readings from the article along with the picture to enhance their understanding of how natural gas is extracted in the fracking process.

\section{Day 2. How to Better Understand Fracking}

The students were asked to respond to the following questions:

c) What is fracking?

d) What is the purpose of fracking?

All of the students $(100 \%)$ stated in their written responses that fracking is the process of drilling into shale rocks and injecting high pressured water to extract gas and oil. All of the students (100\%) also stated that 
fracking provides access to hard to reach oil and natural gas. After answering these questions, the students were provided with a video that shows the steps of fracking ( https://www.nationalgeographic.org/media/howhydraulic-fracturing-works/). Based on the information provided in the video, the students were asked to determine the risks that are associated with each step. Finally, the students were asked to respond to the following questions:

c) What potential impact does fracking have on the environment?

d) Did your opinion on fracking change after this activity?

Below is a list of responses to question C generated by the students (80\%) who were opposed fracking:

1. Fracking affects air quality

2. Fracking might cause chemicals to leak in the drinking water causing pollution

3. Fracking could potentially cause human death

4. Fracking cause earthquakes

5. Fracking use a large amount of water

6. Fracking can cause energy independence

The listed items above indicate the students' concerns about fracking. They believe the fracking has the potential to cause harm to the environment as well as human health. In response to the question asking if the activity change opinions, the data shows that students changed their position in supporting or opposing fracking by the end of the unit. The majority of the students, who were opposed to fracking before (80\%) and after the unit $(62 \%)$, stated that the practice has the potential to cause damage to the environment as well as drinking water resources. By the end of the unit, 18\% of these students switched their position to support fracking. These students stated that there is not enough evidence to support the notion that fracking causes harm to the environment. The students who supported fracking initially (20\%) held firm to their beliefs that it will allows the United States to become energy independent and provide high paying jobs for people. The students who switched their position and supported fracking (18\%) also supported the idea that the fracking will lead to energy independence and jobs that will bring need income and support to the economy.

\section{Day 3: Review the Pros and Cons of Fracking}

The students were assigned the Newsela article titled, "Issue Overview: Fracking" (https://newsela.com/read/overview-fracking/id/21698/). This article was assigned to reinforce the students' reading comprehension and point of view for the pros and cons of fracking. This was done so that the students could better solidify their stance on fracking. The students were asked to read and take note of the various positions on fracking and then come up with their lists in groups. This allows them to organize better the information that is presented to them in the article.

The students were then presented with a unique way to share their thoughts on the article. They were asked to use Twitter-style ( 280 characters) response to summarize the main point of the article. The students were very engaged in this activity to the point where they calculated the number of characters in their summary to ensure they were able to express their view accurately with no fewer characters. The students written responses were assessed for the following:

a. Evidence in their written statements on what the article was about

b. Evidence of pros and cons used in the article

c. Students' abilities to generate their own conclusion from the article

Below are two examples of Twitter-style group responses from students who support and oppose fracking.

Student 1:

The article was about how fracking might be good or bad. It's bad because it speeds up global warming, it's like coal mining, and dangerous. But, it could be good since it potentially may create lots of jobs and lead to energy independence. There are no signs of pollution from fracking. These things are important, so I support fracking. 
Student 2:

Overall, the main idea of the article was about whether fracking is good or not. There were many, many reasons why or why not, but there are more reasons why fracking should be allowed. But in my personal opinion on this topic, I would say that there shouldn't be any fracking allowed.

Table 4. Advertise fracking

\begin{tabular}{ll}
\hline \multicolumn{1}{c}{ Position: For (Advertise) or Against (Outlaw) Fracking? } \\
\hline \multicolumn{1}{c}{ Supporting Statements } & \multicolumn{1}{c}{ Supporting Evidence (from your research) } \\
\hline $\begin{array}{l}\text { Reason 1: It can create many jobs for the US and } \\
\text { UK. }\end{array}$ & $\begin{array}{l}\text { Evidence: For the USA, it has already created many } \\
\text { jobs. For the UK, research has proven that it will } \\
\text { most likely create more jobs. }\end{array}$ \\
$\begin{array}{l}\text { Reason 2: It has created and will create enough } \\
\text { energy for the future. }\end{array}$ & $\begin{array}{l}\text { Evidence: For the USA, it has already created } \\
\text { enough energy so that we don't have to import. For } \\
\text { the UK, it will create a lot of energy and economic } \\
\text { boom. }\end{array}$ \\
$\begin{array}{l}\text { Reason 3: All of the effects that fracking cause can } \\
\text { be reduced. }\end{array}$ & $\begin{array}{l}\text { Evidence: It has already reduced carbon emissions } \\
\text { as fuel like coal is rarely used and natural gas }\end{array}$ \\
& $\begin{array}{l}\text { We can prevent methane leaks by testing and } \\
\text { repairing valves. We can reduce risks of small } \\
\text { earthquakes by mapping deep rock formation and }\end{array}$ \\
& avoiding where tremors could happen.
\end{tabular}

Conclusion: Even though it can harm the environment, those risks can be reduced, and it is better than coal mining.

Reference: http://www.bbc.com/news/uk-14432401 (Adapted from Bloomberg)

Though they were asked to summarize the main points of the article using 280 characters, the students (100\%) ensured they included their beliefs about fracking. The purpose of the Twitter style activity was to allow the students to practice their reading comprehension and writing skills in a social media type atmosphere. Such approach caters to the young learners because it will enable them to be creative in a format that they understand (Twitter) that practices concise expression of their thoughts in words. The exemplar above shows that this student was able to write concisely about what the article was about. The student correctly stated that the article was about the pros and cons of fracking and the associated reasons for both sides of whether to allow fracking.

\section{Day 4: Should Fracking be outlawed in Massachusetts?}

The students were asked to record their responses to the above question in the graphic organizer below. This graphic organizer allowed the students to build upon the previous day's work by requiring them to pick a stance on fracking, use reasons, provide evidence from their research, and record these in the graphic organizer below. Having this graphic organizer allows the students to organize their point of view in a meaningful way. Table 4 below is a common exemplar of a completed organizer from a student who supported fracking. In the above exemplar, this student gave three good reasons with supporting evidence to strengthen his position that fracking should be allowed in the United States. For example, one of the reasons this student gave for supporting fracking is that it can create many jobs. To substantiate this reason, the student used text-based evidence to support his stance on fracking. Table 5 below is a typical example of a student who was opposed to hydraulic fracturing in Massachusetts.

In the below exemplar, this student was able to use text-based evidence to support her stance against fracking. For example, the student stated that from her research, she learned that methane emission, as well as other greenhouse gas emissions, can release into the environment and cause potential problems. The responses from these students clearly show that when students are exposed to a well-planned curriculum, they garner the abilities to enhance their argumentation skills by using evidence to substantiate claims. These students were able to use what they learned from the article they read and the activities they engaged in to provide evidence to support their stance on fracking. 
Table 5. Outlaw fracking

\begin{tabular}{|c|c|}
\hline \multicolumn{2}{|c|}{ Position: For (Advertise) or Against (Outlaw) Fracking? } \\
\hline \multicolumn{2}{|c|}{ I am against fracking in Massachusetts } \\
\hline Supporting Statements & Supporting Evidence (from your research) \\
\hline $\begin{array}{l}\text { Reason 1: The gas could be leaked into our drinking } \\
\text { water supply. }\end{array}$ & $\begin{array}{l}\text { Evidence: Toxic chemicals could leak into the } \\
\text { aquifers. According to my past research, a risk from } \\
\text { the } 2^{\text {nd }} \text { part of fracking that pumped high pressured } \\
\text { water, the water is mixed with chemicals that could } \\
\text { leak into our drinking water. }\end{array}$ \\
\hline $\begin{array}{l}\text { Reason 2: Fracking uses high-pressured water to } \\
\text { break apart the shale rocks. }\end{array}$ & $\begin{array}{l}\text { Evidence: From the fracking worksheet, each } \\
\text { fracking phase requires } 15,000 \text { cubic meters of water, } \\
\text { which is mixed with sand and toxic chemicals. }\end{array}$ \\
\hline $\begin{array}{l}\text { Reason 3: Fracking can cause many damaging } \\
\text { things such as natural disasters. }\end{array}$ & $\begin{array}{l}\text { Evidence: Based on the research, when the high- } \\
\text { pressured water breaks apart the shale rocks, this can } \\
\text { cause things like earthquakes and other natural } \\
\text { disasters. }\end{array}$ \\
\hline \multicolumn{2}{|c|}{$\begin{array}{l}\text { Conclusion: Although, I'm sure you probably don't know what fracking is, I can assure you that it is not a } \\
\text { good thing. Fracking causes leaks into our water supply, uses high pressured water, it can cause natural } \\
\text { disasters. }\end{array}$} \\
\hline Reference & \\
\hline
\end{tabular}

\section{Day 5: The Great Fracking Debate}

This place-based education assignment is meant to be a formative assessment of the students' knowledge of the process of fracking. This allowed the students to further elaborate on the evidence they have gathered. Students had already gathered evidence over the past few lessons, formed opinions/claims based on evidence and reasoning, and now have the chance to pick a side and debate with their peers whether or not fracking should be allowed in their local region. This was done so that students have a closer connection to the topic-if the topic is close to home, it will be more meaningful to the students. Table 6 below shows the outline of the class debate questionnaire that students who typically were opposed to fracking $(62 \%)$ used as they engaged in debates of whether hydraulic fracturing should be banned in Massachusetts.

Table 6. Class debate questionnaire: Students against fracking

$$
\text { I am in favor of: No fracking }
$$

Write 5 valid scientific reasons that support your opinion:

1. Each fracturing well requires 1-8 million gallons of water

2. Contaminate water system in area where fracking is done

3. The potential to release methane into the air

4. Link to Earthquakes or tremors near fracking site

5. Uses hazardous chemicals

Anticipate 5 arguments from the opposing side:

1. Cheaper energy

2. Less carbon emission

3. Create jobs

4. Provide a source of natural gas

5. Lower the value of surrounding land value

Notes: Fracking poses a lot of risk to peoples' health.

Write a least 3 sources you used to support your argument

- https://www.nytimes.com/topic/subject/natural-gas-fracking

- $\quad$ https://www.wired.com/2015/06/frackings-problems-go-deeper-waterpollution/

- https://www.scientificamerican.com/article/fracking-can-contaminatedrinking-water/

- https://www.youtube.com/watch?v=LAxsTJd7VCA 
Table 7 below shows the outline of the class debate questionnaire that students who typically were supportive of fracking (38\%) used as they engaged in debates of whether hydraulic fracturing should be banned in Massachusetts.

Table 7. Class debate questionnaire: Students who support fracking

I am in favor of: Fracking
Write 5 valid scientific reasons that support your opinion:
1. It can lead to our nation becoming energy independent
2. We are not aware of major geologic or environmental impact
3. Fracking offers the potential for major job creation
4. It will provide an enormous boost to our state and local economies
5. There is no record of these activities causing pollution of any kind
Anticipate 5 arguments from the opposing side:
1. We don't yet know for sure what impact fracking has on the movement of
2. Fracking activities drive land values down
3. Similar to drilling for oil or mining for coal
4. It's another example of a means to an end
Fracking contaminate water
Notes: Fracking is good for a lot of reasons
Write a least 3 sources you used to support your argument
• https://www.youtube.com/watch?v=oMboTKOWeAs\&feature=youtu.be
• https://www.youtube.com/watch?v=LAxsTd7VCA
• https://www.youtube.com/watch?v=Uti2niW2BRA

\section{Final Reflection on Hydraulic Fracturing}

The questions below were used as a summative assessment of the unit to gauge how effective the unit was as a whole. It tells whether or not the misconceptions of the students changed based on the research they've conducted as well as how much of an impact the SSI topic of fracking had on the students overall. Below are some typical arguments given by students who did not support fracking at the beginning of the unit of study.

Typical questions from the researcher and responses from the students who were swayed

a) What was your position on fracking at the beginning of the unit (day 1)?

- $\quad$ Fracking should be outlawed because it is bad

b) Did your position change? Why or why not?

- Yes, because when I saw how much more evidence to support fracking, I changed my mind.

c) Was your opinion swayed by any of the information that your peers presented in the debates or posters? Why or why not?

- Yes, because using natural gas is healthier than burning coal.

d) What is the purpose of fracking?

- $\quad$ To extract natural gas from shale rocks.

The students who supported fracking generally made the case that it has the potential to promote energy independence and create high paying jobs for people.

The use of socioscientific issues as a critical pedagogy strategy can enhance students' conceptual understanding of scientific phenomena affecting their daily lives (Powell \& Fuchs, 21019). This study investigated the effects of a place-based socioscientific issues curricular unit of instruction on rising middle school students' abilities to engage in evidence-based reasoning as they critically think about whether or not hydraulic fracturing should be banned in Massachusetts. Throughout this investigation, we saw students shared strong support or opposition to the process of hydraulic fracturing. At the start of the instructional unit, most students $(80 \%)$ were opposed to the practice. The students stated that the hydraulic fracturing process could contaminate drinking water resources, resulting in health problems for people who drink the contaminated water. These students also noted that hydraulic fracturing contributes to Earthquakes. By the end of the instructional unit, there was a slight shift in the percentages $(62 \%)$ of students initially opposed to hydraulic fracturing. The $18 \%$ of students who initially opposed fracking explained that they changed their thoughts from opposing hydraulic fracturing to supporting the practice because the benefits far outweighed the risks. They joined with the group of students who supported 
fracking from the start (20\%) and gave a compelling argument that the practice will generate need gas and oil to make the United States energy independent. These students also stated that jobs generated from hydraulic fracturing would help stimulate the economy since it will provide a livable income for people who work in the industry. These students also stated that there is no real evidence to suggest that the hydraulic fracturing causes Earthquakes or other adverse environmental consequences. These students also indicate that, if anything, hydraulic fracturing will be of benefit to the environment because natural gas burns cleaner than coal.

Both groups of students understood the steps involved in hydraulic fracturing to raise essential arguments about the pros and cons and whether the process should be banned in Massachusetts. The students' statements in support or opposition to hydraulic fracturing are aligned with what of children of similar age and adults. For example, Sarge et al. (2015) conducted a study investigating the public perceptions of hydraulic fracturing and found similar results. In their study, Sarge et al. (2015) had 250 adult participants responded to items asking about their pre-existing attitudes and beliefs regarding hydraulic fracturing.

After responding to these items, the participants then evaluated a series of news photos coded as either presenting the issue's economic benefits or environmental costs. This study found that support for hydraulic fracturing was positively associated with beliefs that it is primarily an economic issue and negatively related to beliefs that it is an environmental issue (Sarge et al., 2015). These results indicate that students and adults hold similar views pertaining to the impact of hydraulic fracturing on the environment, public health, and the environment. While approximately $44 \%$ of the students stated in the pretest that they know very little or nothing at all about oil and natural gas development through the use of hydraulic fracturing, by the end of the instructional unit, $100 \%$ of the students stated fracking is the process of drilling into shale rocks and injecting high pressured water to extract gas and oil. All of the students (100\%) also stated that fracking provides hard-toreach oil and natural gas. The students who opposed hydraulic fracturing noted that the process poses significant risks to human health because of the potential to pollute the air and drinking water resources. Interestingly, these students who were opposed to hydraulic fracturing also acknowledge that the process could allow the United States to become energy independent. However, these students believe the risks associated with the practice outweigh the benefits of becoming energy independent, and as a result, the practice should be banned in Massachusetts. The students who supported hydraulic fracturing believe the opportunity to be energy independent is of paramount importance as this will create well-paying jobs that will ultimately improve the economy.

These views on hydraulic fracturing are similar to what Thomas et al. (2016) have reported. In trying to determine the public perceptions of hydraulic fracturing for shale gas and oil in the United States and Canada, Thomas et al. (2016) reviewed 58 articles on perceptions of hydraulic fracturing published between 2009 and 2015. They reported that individuals tend to have negative associations with the term fracking. The students in the current investigation expressed a similar attitude whenever they heard the word fracking. Thomas et al. (2016) reported that the perceived benefits tend to be economical (e.g., job creation, boosts to local economies) and risks more commonly environmental and social (e.g., impacts on water, increased traffic).

These findings are similar to what was discovered in this study. The instructional unit positively impacted the students' abilities to succinctly identify the pros and cons of hydraulic fracturing, as they use the pros and cons as evidence to reasoned and think critically about whether the process should be banned in Massachusetts. The students identified their position in support or opposition to hydraulic fracturing and provided reasons and evidence to strengthen their conclusion.

The students who supported hydraulic fracturing discussed how the practice is already creating jobs and providing clean energy in the United States. These students believe proper mitigation strategies should be implemented to prevent fracturing adverse effects because the benefits are so crucial to the economy and the environment. The students used what they learned from the instructional unit to effectively used evidence-based reasoning as they critically think and debated debate if hydraulic fracturing should be banned in Massachusetts. The students used information learned from the articles they read to inform their decision on fracking in Massachusetts. They used scientific reasons from the articles they read to support their stance on hydraulic fracturing. They also anticipated counterarguments that their peers with different beliefs would use to contradict their arguments. This allowed the students to engage in substantive discussions that showcase their ability to engage in evidence-based reasoning and critical thinking about hydraulic fracking and whether the practice should be banned in Massachusetts. For example, the student who supported hydraulic discussed that although we are not aware of any significant geologic or environmental impact due to hydraulic fracturing, we don't yet know what impact fracking has on the movement of the earth. As a result, more studies are needed to learn more about the process. However, they believe that the process should still be allowed to continue with caution. The 
students $(18 \%)$ who were opposed to hydraulic fracturing but changed their position talked about how much more evidence is there to support fracking. They talked about how natural gas harvested from hydraulic fracturing is better for the environment as it much cleaner type of fossil fuel.

While many people in society may think rising middle school students are not equipped with the technical knowledge to debate scientific issues that affect their communities, the finding from this investigation proved otherwise. The facts are, if students are exposed to proper guidance to conduct research and are taught how to summarize their conclusions, then they can learn to express themselves in productive ways. The students in this investigation were able to engage in the research on hydraulic fracturing and present compelling arguments supporting their views. The use of SSI to engage students in place-based education can enlighten students on scientific topics that affect their communities. Such pedagogy has the potential of equipping students with the skills necessary for them to become better advocates for themselves and their communities.

\section{Conclusion}

The results obtained from this investigation are very encouraging considering the study was done with rising middle school students who are 11-12 years old. This suggested that SSI when implemented effectively in the curriculum, such pedagogical strategy has the potential to enhance students' abilities to engage in meaningful discourse on scientific issues impacting their communities. The results indicate that students are able to use their understanding of the science and engineering practices to construct valid arguments on whether or not fracking should be allowed in Massachusetts. While many students did not necessarily change their initial thoughts on whether fracking should be banned in Massachusetts, all the students were able to generate arguments from evidence.

\section{Scientific Ethics Declaration}

The author declares that the scientific ethical and legal responsibility of this article published in JESEH journal belongs to the author.

\section{References}

Allen, B. (2003). Uneasy alchemy: Citizens and experts in Louisiana's chemical corridor dispute. Cambridge: MIT Press.

American Association for the Advancement of Science. (1989). Science for all Americans. Washington, DC: American Association for the Advancement of Science.

Annear, S. (2014). Environmentalists: Stay the 'frack' out of Massachusetts health advocates are continuing their fight to ban fracking in the Bay State. City Life. https://www.bostonmagazine.com/news/ 2014/02/20/fracking-massachusetts-protest-letters/

Barth-Naftilan E, Sohng J, \&Saiers J.E. (2018). Methane in groundwater before, during, and after hydraulic fracturing of the Marcellus Shale. Proc Natl Acad. Sci USA, 115:6970-6975.

Bencze, L., Sperling, E., \& Carter, L. (2012). Students' research-informed socio-scientific activism: Re/ visions for a sustainable future. Research in Science Education, 42, 129-148.

Birmingham, D., \& Barton, A. C. (2014). Putting on a green carnival: Youth taking educated action on socioscientifc issues. Journal of Research in Science Teaching, 51(3), 286-314.

Bryant, B.I. \& Mohai, P. (1992). Race and the incidence of environmental hazards. Boulder, CO: Westview Press

Bullard, R.D., Mohai, P., Saha, R., \& Wright, B. (2008). Toxic wastes and race at twenty: why race still matters after all of these years. Environmental Learning. 38(2):371-411.

Carspecken, P. F. (1996). Critical ethnography in educational research. New York: Routledge.

Carter, L. (2011). Gathering in threads in the insensible global world: The wicked problem of globalization and science education [Editorial]. Cultural Studies of Science Education, 6(1), 1-12.

Chokker, K., Dua, S., Taylor, N., Boyes, E., \& Stanisstreet, M. (2011). Indian secondary students' views about global warming: Beliefs about the usefulness of actions and willingness to act. International Journal of Science and Mathematics Education, 9(5), 1167-1188. https://doi.org/10.100710763-010-9254-Z

Colborn, T., Kwiatkowski, C., Schultz, K., \& Bachran, M. (2011). Natural gas operations from a public health perspective. Hum Ecol. Risk Assess.,17(5):1039-1056.

Cooney, A. (01/13/2019). Protesting the pipeline: In Weymouth, the fight continues. The Patriot Ledger. 
https://www.patriotledger.com/news/20190112/protesting-pipeline-in-weymouth-fight-continues

Cutter, S. (1995). Race, class and environmental justice. Progress in Human Geography. 19, 107-18.

Davis, T. (2018). Toxic space and time: Slow violence, necropolitics, and petrochemical pollution. Annals of the American Association of Geographers, 108(6), 1537-1553.

Dawson, V. M., \& Venville, G. (2010). Teaching strategies for developing students' argumentation skills about socio-scientific issues in high school genetics. Research in Science Education, 40(2), 133-148.

Denzin, N., \& Lincoln, Y. (2011). The Sage handbook of qualitative research. Thousand Oaks California: SAGE Publications, Inc.

Ellsworth, W. L. (2013). Injection-induced earthquakes. Science, 341, 1225924, https://doi.org/ 10.1126/science.1225942.

Environmental Protection Agency (2016). Hydraulic fracturing for oil and gas: Impacts from the hydraulic fracturing water cycle on drinking water resources in the United States. Environmental Protection Agency, Washington, DC, Report EPA/600/R-16/236F.

Ferrar, K.J, Michanowicz, D.R, Christen, CL, Mulcahy, N., Malone, S.L., \& Sharma, R.K. (2013). Assessment of effluent contaminants from three facilities discharging Marcellus Shale wastewater to surface waters in Pennsylvania. Environmental Science Technology, 47(7):3472-3481.

Glaser, B., \& Strauss, A. (1967). The discovery of grounded theory. Chicago: Aldine.

Griffith, J., Duncan, R.C., Riggan, W.B., \&Pellom, A.C. (1989). Cancer mortality in US counties with hazardous waste sites and ground water pollution. Arch Environ Health, 44(2):69-74.

Harvard Graduate School of Education. (2009). Visible thinking resource book. Downloaded on May 11, 2020 http://www.pz.harvard.edu/vt/

Hermans, M., \& Korhonen, J. (2017). Ninth graders and climate change: Attitudes towards consequences, views on mitigation, and predictors of willingness to act. International Research in Geographical and Environmental Education, 26(3), 223-239. https://doi.org/10.1080/10382046.2017.1330035

Howley, C., \& Harmon, H. (2000). Community as tacit curriculum. In C. Howley \& H. Harmon (Eds.), Small high schools that flourish: Rural cases and resources (pp. 61-88). Charleston, WV: AEL, Inc. (ERIC Document Reproduction Service No. 447 998).

Howley, A., Howley, C., Burgess, L., \& Pusateri, D. (2008). Social class, Amish culture, and an egalitarian ethos: Case study from a rural school serving Amish children. Journal of Research in Rural Education, 23(3), 1-12. http://www.jrre.psu.edu/.

Howley, C., \& Howley, A. (2010). Poverty and school achievement in rural communities: A social class interpretation. In K. Schafft \& A. Jackson (Eds.), Rural education for the twenty-first century: Identity, place, and community in a globalizing world (pp. 34-50). University Park, PA: Pennsylvania State University Press.

Jasechko, S., \& Perrone, D. (2017). Hydraulic fracturing near domestic groundwater wells. Proceedings of the National Academy of Sciences of the United States of America, 114(50), 13,138-13,143.

Jennings, N., Swidler, S., \& Koliba, C. (2005). Place-based education in the standards-based reform-era: Conflict or complement? American Journal of Education, 112(1), 44-65.

Johnston, J.E, Werder, E, \& Sebastian, D. (2016). Wastewater disposal wells, fracking, and environmental injustice in Southern Texas. Am J Public Health, 106(3):550- 556, PMID: 26794166, https://doi.org/10.2105/AJPH.2015.303000.

Keehan, C.J. (2018). Lessons from cancer alley: How the clean air act has failed to protect public health in Southern Louisiana. Colo. Nat. Resources, Energy \& Envtl. L. Rev. 29(2): 341-371

Klosterman, M.L. \& Sadler, T.D. (2010). Multi-level assessment of scientific content knowledge gains associated with socioscientific issues-based instruction. International Journal of Science Education, 32(8), 1017-1043, https://doi.org/10.1080/09500690902894512

LeCompte, M., \& Schensul, J. (1999). Designing \& conducting ethnographic research (Vol. 1). Rowman Altamira, London.

Lewicki, J. (1998). Cooperative ecology and place: Development of a pedagogy of place curriculum. http://www.eric.ed.gov/PDFS/ED461461.pdf

Louisiana Department of Environmental Quality (1997). Louisiana toxics release inventory report 1997. Baton Rouge: LEDQ.

Lowman, A, McDonald, MA, Wing, S, \& Muhammad, N. (2013). Land application of treated sewage sludge: community health and environmental justice. Environ Health Perspect. 121(5):537-542.

Lutz, B.D., Lewis, A.N., \& Doyle, M.W. (2013). Generation, transport, and disposal of wastewater associated with Marcellus Shale gas development. Water Resour. Res. 49(2):647-656.

Mueller, M.P., Zeidler, D.L., \& Jenkins, L.L. (2011). Earth's role in moral reasoning and functional scientific literacy. In J. L. DeVitis \& T. Yu (Eds.), Character and moral education: a reader (pp. 382-391). New York: Peter Lang. 
Mulnix, J.W. \& Mulnix, M. J. (2010). Using a writing portfolio project to teach critical thinking skills. Teaching Philosophy, 33(1), 27-54.

National Research Council (2012). A framework for K-12 science education: Practices, crosscutting concepts, and core ideas. Committee on conceptual framework for the new K-12 science education standards, Board on Science Education, National Research Council. Washington, DC: National Academies Press.

Norton, J.M., Wing, S., Lipscomb, H.J., Kaufman, J.S., Marshall, S.W., \& Cravey, A.J. (2007). Race, wealth, and solid waste facilities in North Carolina. Environ Health Perspect. 115(9):1344-1350.

Osborn, S.G., Vengosh, A., Warner, N.R., \& Jackson, R.B. (2011). Methane contamination of drinking water accompanying gas-well drilling and hydraulic fracturing. Proc Natl Acad Sci USA 108(20):8172-8176.

Powell, W.A., \& Fuchs, D. (2019). Using socioscientific issues to enhance evidence-based reasoning among middle school students. In S. Robinson \& V. Knight (Eds.), Handbook of Research on Critical Thinking and Teacher Education Pedagogy (pp. 150-176). IGI Global.

Ross, C, Rogers, C, \& Duff, D. (2016). Critical ethnography: An under used research methodology in neuroscience nursing. Canadian Journal of Neuroscience Nursing, 38, 1, 4-7.

Sadler, T. D. (2004). Informal reasoning regarding socioscientific issues: A critical review of research. Journal of Research in Science Teaching, 41, 513-536.

Sadler, T. D., Klosterman, M. L., \& Topcu, M. S. (2011). Learning science content and socioscientific reasoning through classroom explorations of global climate change. In T. D. Sadler (Ed.), Socio-scientific issues in science classrooms: Teaching, learning and research (pp. 45-77). The Netherlands: Springer.

Sadler, T. D., \& Murakami, C. D. (2014). Socio-scientific issues-based teaching and learning: Hydrofracturing as an illustrative context of a framework for implementation and research. Brazilian Journal of Research in Science Education, 14(2), 331-342.

Sarge, M.A., VanDyke, M.S., King, A.J.,\& White, S.R. (2015). Selective perceptions of hydraulic fracturing: The role of issue support in the evaluation of visual frames. Politics and the Life Sciences, 34 (1), 57 72.

Sarkar, S., \& Frazier, R. (2008). Place-based investigations and authentic inquiry. The Science Teacher, 75, 2933.

Schwandt, T. A. (1997). Qualitative inquiry: A dictionary of terms. Thousand Oaks, CA: Sage.

Singer, M. (2011). Down cancer alley: The lived experience of health and environmental suffering in Louisiana's chemical corridor. Medical Anthropology Quarterly 25 (2):141-63. https://doi. org/10.1111/j.1548-1387.2011.01154.x

Skamp, K., Boyes, E., \& Stanisstreet, M. (2013). Beliefs and willingness to act about global warming: Where to focus science pedagogy? Science Education, 97, 191-217.

Slavin R. E., \& Sharan S. (1990). Comprehensive cooperative learning methods: Embedding cooperative learning in the curriculum and school. Cooperative learning: Theory and research. New York: Preston Press.

Smyth, W., \& Holmes, C. (2005). Using Carspecken's critical ethnography in nursing research. Contemporary Nurse, 19(1-2), 65-74.

Sobel, D. (2004). Place-based education: Connecting classrooms and community. Nature and listening, 4(1), 17.

Stossel, J. (2014, October 1). The Frack Attack [Video]. YouTube. https://www.youtube.com/watch?v=iILUxumUu40

Theobald, P. (1997). Teaching the commons: Place, pride, and the renewal of community. Boulder, CO: Westview Press.

Thomas, M.J., Pidgeon, N.F., Evensen, D.T., Partridge, T., Hasell, A., Enders, C., \& Herr-Harthorn, B. (2016). Public perceptions of shale gas operations in the USA and Canada: A review of evidence. M4 ShaleGas Consortium: Utrecht, The Netherlands.

Environmental Protection Agency (1992a). Environmental equity: reducing risk for all communities. Washington, DC: Government Printing Office. EPA Journal,18, 1-64.

Vengosh, A, Jackson, R.B., Warner, N., Darrah, T.H., \& Kondash, A. (2014). Acritical review of the risks to water resources from unconventional shale gas development and hydraulic fracturing in the United States. Environ Sci Technol. 48(15):8334-8348.

Weiskel, P. W. \& Green-Weiskel, L. (2017). Protecting Western Massachusetts farms: Down with fracking and the kinder morgan pipeline. HUFFPOST. https://www.huffpost.com/entry/kindermorgan-gas-pipeline-fracking_b_5592574

What is fracking and why is it controversial? (2018). Downloaded on January 5, 2019 http://www.bbc.com/news/uk-14432401.

Yap, S. F. (2014). Beliefs, values, ethics and moral reasoning in socio-scientific education. Issues in Educational Research, 24 (3), 299-319. 
Yuan, Z., Gardoni, P., Schubert, J.,\& Teodoriu, C. (2013). Cement failure probability analysis in water injection well. J Petrol Sci Eng. 107, 45-49.

Zeidler, D.L. \& Kahn, S. (2014). It's debatable! Using socioscientific issues to develop scientific literacy, K-12. Arlington, VA: NSTA Press.

\title{
Author(s) Information
}

\author{
Wardell A. Powell \\ Framingham State University \\ College of Education \& Social and Behavioral \\ Sciences, O'Connor Hall 136 \\ 100 State Street \\ Framingham, MA 01701, U.S.A. \\ (508) 626-4830 \\ Contact e-mail: wpowell1@framingham.edu \\ ORCID iD: 0000-0002-3486-2077
}

